\title{
Selection, dominance and atresia of follicles during the oestrous cycle of heifers
}

\author{
S. J. Sunderland ${ }^{1}$, M. A. Crowe ${ }^{1}$, M. P. Boland ${ }^{2}$, J. F. Roche ${ }^{1}$ and \\ J. J. Ireland ${ }^{3}$ \\ Faculties of ${ }^{1}$ Veterinary Medicine and ${ }^{2}$ Agriculture, University College Dublin, Ireland; and ${ }^{3}$ Molecular \\ Reproductive Endocrinology Laboratory, Department of Animal Science, Michigan State University, \\ East Lansing, MI 48823, USA
}

\begin{abstract}
This study examined the correlation between measurement of follicle growth by ultrasound, and measurement of intrafollicular ratios of oestradiol and progesterone concentrations and the serum concentrations of FSH during selection, dominance and atresia or ovulation of dominant follicles in heifers. Heifers were ovariectomized on days 0 (before LH surge), 1 (after LH surge, preovulation), I (postovulation), 3, 6 and 12 of the oestrous cycle. Blood samples were collected at $4-6 \mathrm{~h}$ intervals. After ovariectomy all follicles $\geq 5 \mathrm{~mm}$ were measured and follicular fluid was aspirated. Follicles were classified by size according to ultrasound (F1, largest; F2, second largest; F3, all remaining follicles $\geq 5 \mathrm{~mm}$ ) and by the ratio of oestradiol:progesterone concentrations. During the follicular phase, a single dominant oestrogen-active follicle increased in diameter while serum concentrations of $\mathrm{LH}$ increased and FSH decreased $(P<0.05)$. On day 1 (after LH surge, preovulation), serum LH and FSH decreased to pre-surge concentrations $(P<0.0001)$, while follicle size and intrafollicular progesterone concentration increased and oestradiol concentration decreased $(P<0.05)$. A dominant nonovulatory follicle, classified as oestrogen-active on days 1,3 and 6 and oestrogen-inactive on day 12 , increased in size from day 1 to day 7 and lost dominance during days 10-12, coincident with the growth of multiple oestrogen-active follicles. The serum FSH concentration increased transiently $(P<0.05)$ before each new wave of dominant follicular growth. The overall correlation of ultrasound measurements of follicle diameter with measures of follicle size after ovariectomy was high. The ratio of oestradiol:progesterone concentrations, but not of size, reliably distinguished potential dominant from atretic follicles. The size of the follicle and the oestradiol concentration were not determinants of subsequent dominance during a selection phase. We conclude that: (1) ovarian follicles go through selection, dominance and atresia phases coincident with transient increases and decreases in $\mathrm{FSH}$; and (2) ultrasound is an accurate measure of follicle growth, but that size alone is not a sufficient measure to ascribe dominance and both ultrasound and the intrafollicular ratio of oestradiol:progesterone concentrations are needed to monitor selection, dominance and atresia of follicles accurately.
\end{abstract}

\section{Introduction}

Antral follicles were originally considered to be in a continuous state of turnover without distinct patterns of growth and atresia during the oestrous cycle of heifers (Choudary et al., 1968; Marion et al., 1968; Dufour et al., 1972). However, the classic histological study of Rajakoski (1960), coupled with the direct follicle-marking studies of Matton et al. (1981), indicated that at least two periods of turnover of antral follicles occur during the oestrous cycle of cattle. One follicle grows to ovulatory size $(>10 \mathrm{~mm})$ and undergoes atresia during early dioestrus (days 6-12) and another follicle grows to ovulatory

Received 6 September 1993 size from luteolysis (day 18) to oestrus (day 0) during the follicular phase and ovulates on day 1 of the cycle (Matton et al., 1981). Ireland and Roche (1982, 1983a, b, 1987) demonstrated that the intrafollicular ratio of oestradiol:progesterone concentrations can be used to distinguish healthy growing from atretic bovine follicles ( $\geq 6 \mathrm{~mm}$ in diameter), and confirmed and extended the earlier studies on follicular turnover in heifers as follows: (i) a single large ( $>10 \mathrm{~mm}$ ) oestrogen-active follicle (ratio of oestradiol:progesterone concentrations $>1$ in follicular fluid) is present during oestrus and early dioestrus of heifers; (ii) the number of $\mathrm{LH}$ receptors increases while the number of FSH receptors decreases during the growth of oestrogen-active follicles during oestrus and early dioestrus (Ireland and Roche, 1983a, b); (iii) the serum concentration of 
oestradiol increases in only one, rather than in both, uteroovarian veins during oestrus, early dioestrus and mid-dioestrus (Ireland et al., 1985); and (iv) oestrogen-active follicles should be classified as dominant because of their similarity to dominant follicles in primates (Goodman and Hodgen, 1983).

These results led to the hypothesis that heifers have three different periods of development of dominant follicles during an oestrous cycle (oestrus, early dioestrus and mid-dioestrus), and that each period of dominant follicle growth has three distinct phases: selection, dominance and atresia or ovulation (Ireland, 1987; Ireland and Roche, 1987). Selection is a hypothetical physiological process whereby 'excess' follicles are reduced to the ovulatory quota, whereas dominance is a process that enables the 'selected' follicle to suppress further growth of other follicles, escape initial atresia and continue to grow until ovulation or atresia (Goodman and Hodgen, 1983). In support of this model of a dominant follicle in heifers, workers in several laboratories have used ultrasound scanning to monitor daily individual follicle growth and confirm that heifers indeed have three (sometimes two and rarely one) different periods of turnover of dominant follicles (Savio et al., 1988; Sirois and Fortune, 1988; Knopf et al., 1989). Nevertheless, the precise correlation between ultrasound analysis of dominant follicle growth, which is now routinely used to monitor growth of antral follicles in both beef and dairy cows (Murphy et al., 1990; Savio et al., 1990; Crowe et al., 1993), and changes in intrafollicular concentrations of oestradiol and progesterone, which is used to distinguish dominant from atretic follicles (Ireland and Roche, 1982, 1983a, b, 1987), has not been examined. The objectives of this experiment were therefore to: (i) examine the interrelationship of ultrasound measurements of follicle growth, intrafollicular ratios of oestradiol and progesterone concentrations and the serum concentrations of FSH during selection, dominance and atresia or ovulation of dominant follicles in heifers; (ii) evaluate the accuracy of ultrasound measurements of follicular size with postovariectomy measurements of follicle diameter and function; and (iii) use the results of this study to re-evaluate our original model for dominant follicle growth in heifers (Ireland, 1987; Ireland and Roche, 1987).

\section{Materials and Methods}

\section{Animals, maintenance and synchronization of oestrus}

Thirty-three cyclic Simmental crossbred, Hereford crossbred and Charolais crossbred beef heifers, 15-18 months of age and weighing $334-418 \mathrm{~kg}$ at the start of the experiment, were housed on slatted flooring, and had free access to grass silage and water and a daily supplement of $2 \mathrm{~kg}$ of a $16 \%$ crude protein concentrate. To synchronize oestrus, each heifer received a s.c. progestagen ear implant for 10 days (norgestomet: Crestar, Intervet Ireland Ltd, Finglas, Dublin). Two days before implant removal, a single injection (i.m.) of $\mathrm{PGF}_{2 \alpha}$ analogue $\left(\mathrm{PGF}_{2 \alpha}\right.$ : Prosolvin: Intervet Ireland $\mathrm{Ltd}$ ) was administered to initiate luteolysis. After implant removal, heifers were observed for oestrous behaviour for $30 \mathrm{~min}$ at $06: 00 \mathrm{~h}, 12: 00 \mathrm{~h}, 16: 00 \mathrm{~h}$, 20:00 $\mathrm{h}$ and 00:00 h every day until oestrus was detected.

\section{Treatments}

Both ovaries were removed from six different groups of heifers (treatments I-VI) during the following phases or days of the oestrous cycle (day 0 , the day of oestrus): (I) follicular phase ( $n=5$ heifers) $36 \mathrm{~h}$ after an injection of $\mathrm{PGF}_{2 \alpha^{\prime}}$ but before the preovulatory LH surge; (II) day 1 ( $n=6$ heifers) after the preovulatory LH surge and oestrus, but before ovulation ( - ov); (III) day I ( $n=5$ heifers) after ovulation ( + ov); (IV) day $3(n=6$ heifers); (V) day $6(n=5$ heifers) and (VI) day 12 ( $n=6$ heifers). The times for ovariectomy were chosen because they coincided with periods of the oestrous cycle when a dominant ovulatory follicle develops and ovulates (after PGF $_{2 \alpha}$ injection until day 1 ) or when a dominant nonovulatory follicle develops, loses 'dominance' and begins to undergo atresia (days 1-12) (Ireland and Roche, 1982, 1987; Savio et al., 1988). Loss of dominance was functionally defined as the day of the oestrous cycle when a new cohort of follicles $\geq 5 \mathrm{~mm}$ could first be identified by ultrasound scanning while the previous dominant follicle was present. In our study, loss of dominance for the early dioestrous dominant follicle occurred 11.8 \pm 0.75 days (mean $\pm \mathrm{SEM}, n=6$ heifers) after oestrus, referred to above as day 12 of the oestrous cycle (treatment VI).

Animals were not fasted before surgery and each heifer was prepared for surgery, anaesthetized and ovaries removed with an ecraseur, as described by Drost et al. (1992). All animal experimentation was performed in compliance with regulations set down by the BioMedical Centre, University College Dublin, and the Cruelty to Animals Act (Ireland), 1897. After ovariectomy, ovaries were placed in a $50 \mathrm{ml}$ falcon tube containing ice-cold PBS, pH 7.4. Within $30 \mathrm{~min}$ of ovariectomy, all follicles $\geq 5 \mathrm{~mm}$ were counted and the diameter of each follicle was determined using a calliper. Follicular fluid was aspirated from each follicle, its volume recorded and the follicular fluid from each follicle stored separately and frozen at $-20^{\circ} \mathrm{C}$ until hormone assays were performed. Concentrations of oestradiol and progesterone were determined for each follicular sample by radioimmunoassay and the ratio of oestradiol:progesterone in follicular fluid was used to classify follicles as oestrogen-active (oestradiol $>$ progesterone) or oestrogen-inactive (oestradiol < progesterone).

\section{Ultrasound scanning of follicles}

From the time of prostaglandin injection until approximately $14 \mathrm{~h}$ before ovariectomy, the ovaries of each heifer were scanned daily with a transrectal $7.5 \mathrm{MHz}$ linear transducer (Dynamic Imaging Ltd, Livingston), and the number, size and location of each follicle $\geq 5 \mathrm{~mm}$ was recorded daily, as described by Savio et al. (1988). Follicles were placed into three classes based on ultrasound analysis: F1, the largest or the dominant follicle (as defined by Savio et al., 1988); F2, the second largest follicle; and F3, all other follicles $\geq 5 \mathrm{~mm}$.

\section{Collection of blood samples}

The stage of the oestrous cycle was confirmed by collecting samples of blood $(10 \mathrm{ml})$ daily to measure both oestradiol and 
progesterone concentrations via jugular venepuncture from the time of $\mathrm{PGF}_{2 \alpha}$ injection ( 2 days before implant removal) until ovariectomy. In addition, samples were collected from each heifer every 4 or $6 \mathrm{~h}$ from $36 \mathrm{~h}$ after $\mathrm{PGF}_{2 \alpha}$ administration until the time of ovariectomy to establish when the preovulatory $\mathrm{LH}$ surge occurred and to determine changes in circulating concentrations of FSH. Each blood sample was maintained at room temperature for $60 \mathrm{~min}$, at $4^{\circ} \mathrm{C}$ overnight, centrifuged at $700 \mathrm{~g}$ for $20 \mathrm{~min}$ and the serum was stored at $-20^{\circ} \mathrm{C}$ until assays were performed.

\section{Hormone assays}

Previously validated radioimmunoassays were used to quantify oestradiol (Moran et al., 1991), progesterone (Ronayne and Hynes, 1990) and LH (Niswender et al., 1969) concentrations. The sensitivities of the progesterone, oestradiol and LH assays were $0.2 \mathrm{ng} \mathrm{ml}^{-1}, 1.5 \mathrm{pg} \mathrm{ml}^{-1}$ and $0.2 \mathrm{ng} \mathrm{ml}^{-1}$, respectively. Serum FSH concentrations were quantified using a heterologous assay as described by Glencross et al. (1992) using the NIDDK-anti-oFSH antibody and bovine FSH standard preparation (NIH BI bFSH). The sensitivity of the assay was $1.6 \mathrm{ng}$ FSH ml ${ }^{-1}$. Interassay coefficients of variation $(\mathrm{CV})$ for the oestradiol assays averaged 11.3 and $15.4 \%$ for serum samples containing 0.5 and $20.2 \mathrm{pg}$ oestradiol $\mathrm{ml}^{-1}$, respectively. Intra-assay $\mathrm{CV}$ for the same serum pools were 10.9 and $8.8 \%$, respectively. Interassay $\mathrm{CV}$ for the progesterone assays averaged 9.3 and $6.5 \%$ for serum samples containing 0.9 and $3.0 \mathrm{ng}$ progesterone $\mathrm{ml}^{-1}$, respectively. Intra-assay $\mathrm{CV}$ for the same serum pools were 6.5 and $5.7 \%$, respectively. Interassay CV for the LH assays averaged 15.7 and $12.6 \%$ for serum samples containing 3.9 and $26 \mathrm{ng} \mathrm{LH} \mathrm{ml}{ }^{-1}$, respectively. Intra-assay $\mathrm{CV}$ for the same serum pools were 12.9 and $10.8 \%$, respectively. Interassay $\mathrm{CV}$ for the $\mathrm{FSH}$ assays for three serum pools containing $13.9,27$ and $84 \mathrm{ng} \mathrm{FSH} \mathrm{ml}^{-1}$ averaged $9.9,11.9$ and $11.2 \%$, respectively. Intra-assay $\mathrm{CV}$ for the same serum pools were $4.7,6.9$ and $9.5 \%$, respectively.

\section{Statistical analyses}

Follicular development during the oestrous cycle was evaluated using several different statistical analyses with the computer programs of SYSTAT (1990) and the general linear model of SAS (1986).

A split-plot repeat measure analysis was used to examine whether diameter of follicles determined by the last ultrasound measurement before ovariectomy and measurement of diameter by calliper, volume of follicular fluid, intrafollicular concentrations of oestradiol and progesterone, and the ratio of oestradiol:progesterone concentrations in follicular fluid of the same follicles established after ovariectomy differed $(P<0.05)$ among the six groups (I-VI) of heifers and the three follicle classes. If a significant $(P<0.1)$ statistical interaction was observed, the Bonferroni $t$ test was used to test whether means for the F1 follicle class differed $(P<0.05)$ from the F2 and F3 follicle classes for each group of heifers. There were usually $1-3$ follicles $\geq 5 \mathrm{~mm}$ per pair of ovaries the growth of which was accurately monitored by ultrasound. Because the SEM values increased with means, all data were log-transformed (base 10) before statistical analysis; arithmetic means are reported in the text.

Regression analysis was used to determine the correlation of the last ultrasound measurement of follicle size (taken approximately $14 \mathrm{~h}$ before ovariectomy) with measurements of diameter, volume of follicular fluid, intrafollicular concentrations of oestradiol and progesterone, and the ratio of oestradiol: progesterone concentrations in follicular fluid from the same follicles established after ovariectomy from each of the six groups of heifers, for each follicle class (F1, F2, F3) and overall $\left(\mathrm{F} 1+\mathrm{F}_{2}+\mathrm{F} 3\right)$.

To determine whether follicle size on days $1-6$ could be used to predict whether a follicle would become dominant was investigated using regression analysis. This evaluated whether the proportion of the largest follicles on days 1-6 that were classified as dominant by ultrasound on days 6 and 12 varied during days $1-6$.

McNemar's test (Gill, 1978) was used to determine whether there was a difference between the proportion of the largest follicles determined by ultrasound before ovariectomy and the proportion of largest follicles measured after ovariectomy that had the greatest concentration of oestradiol, progesterone, oestradiol:progesterone or progesterone:oestradiol ratios in follicular fluid $(P<0.05)$.

Changes in hormone concentrations throughout the study were evaluated by comparing mean hormone concentrations at different time points using paired $t$ test analysis.

\section{Results}

The follicular phase of the oestrous cycle of heifers began coincident with luteolysis on day -4 (4 days before oestrus), when the mean serum concentration of progesterone was $<2.0 \mathrm{ng} \mathrm{ml}^{-1}$, and ended on day $1(-\mathrm{ov})$, concomitant with ovulation (Fig. 1a). Day 0 was defined as the time of oestrus and the preovulatory gonadotrophin surges. From day -4 to day -1 each heifer had a single dominant ovulatory follicle (F1) that increased $(P<0.05)$ from $11.6 \pm 0.9 \mathrm{~mm}$ to $16 \pm 0.6 \mathrm{~mm}$ in diameter coincident with a sustained basal increase $(P<0.05)$ in the serum concentration of oestradiol, a decrease $(P<0.05)$ in the serum concentration of FSH and progesterone and with no change in LH concentration. After the occurrence of the preovulatory LH and FSH surges on day 0 , the serum concentration of LH, FSH and oestradiol decreased $(P<0.0001)$ to presurge values within $12 \mathrm{~h}$, and the diameter of the dominant ovulatory follicle increased to its maximum size of $18 \pm 0.8 \mathrm{~mm}$. As the F2 and F3 follicles were $<5 \mathrm{~mm}$ in diameter between days -4 and 0 , their growth patterns were not measured.

On days 0 and 1 ( - ov), dominant ovulatory follicles (F1) were classified as oestrogen-active, whereas F2 and F3 follicles were oestrogen-inactive (Figs 1c, 2). Diameter, oestradiol concentrations, and the ratio of oestradiol:progesterone concentration in follicular fluid were greater $(P<0.01)$ for dominant ovulatory follicles compared with F2 follicles (Figs 1, 2). In contrast, the concentration of progesterone was higher $(P<0.01)$ in $\mathrm{F} 2$ than in dominant ovulatory follicles (Fig. 2). Concentrations of oestradiol and the ratio of oestradiol: progesterone concentrations in F1 follicles were two and five 
times lower $(P<0.02)$, respectively, whereas the progesterone concentration was higher $(P<0.01)$ in dominant ovulatory follicles on day 1 ( - ov) after the preovulatory gonadotrophin surge compared with values on day 0 (Fig. 2). Concentrations of oestradiol, progesterone and the ratio of oestradiol: progesterone concentrations in follicular fluid were highly correlated $(r>0.75 ; P<0.05)$ with changes in size of domi- nant ovulatory follicles on day 0 , but not on day 1 ( - ov) (Table 1)

The luteal phase of the oestrous cycle of heifers began on day $I(+o v)$ after ovulation, when serum concentrations of progesterone were less than $0.5 \mathrm{ng} \mathrm{ml}^{-1}$, and ended on day 12. Each heifer had a single dominant nonovulatory (F1) follicle that increased $(P<0.05)$ in diameter from $6.2 \pm 0.3 \mathrm{~mm}$ on day
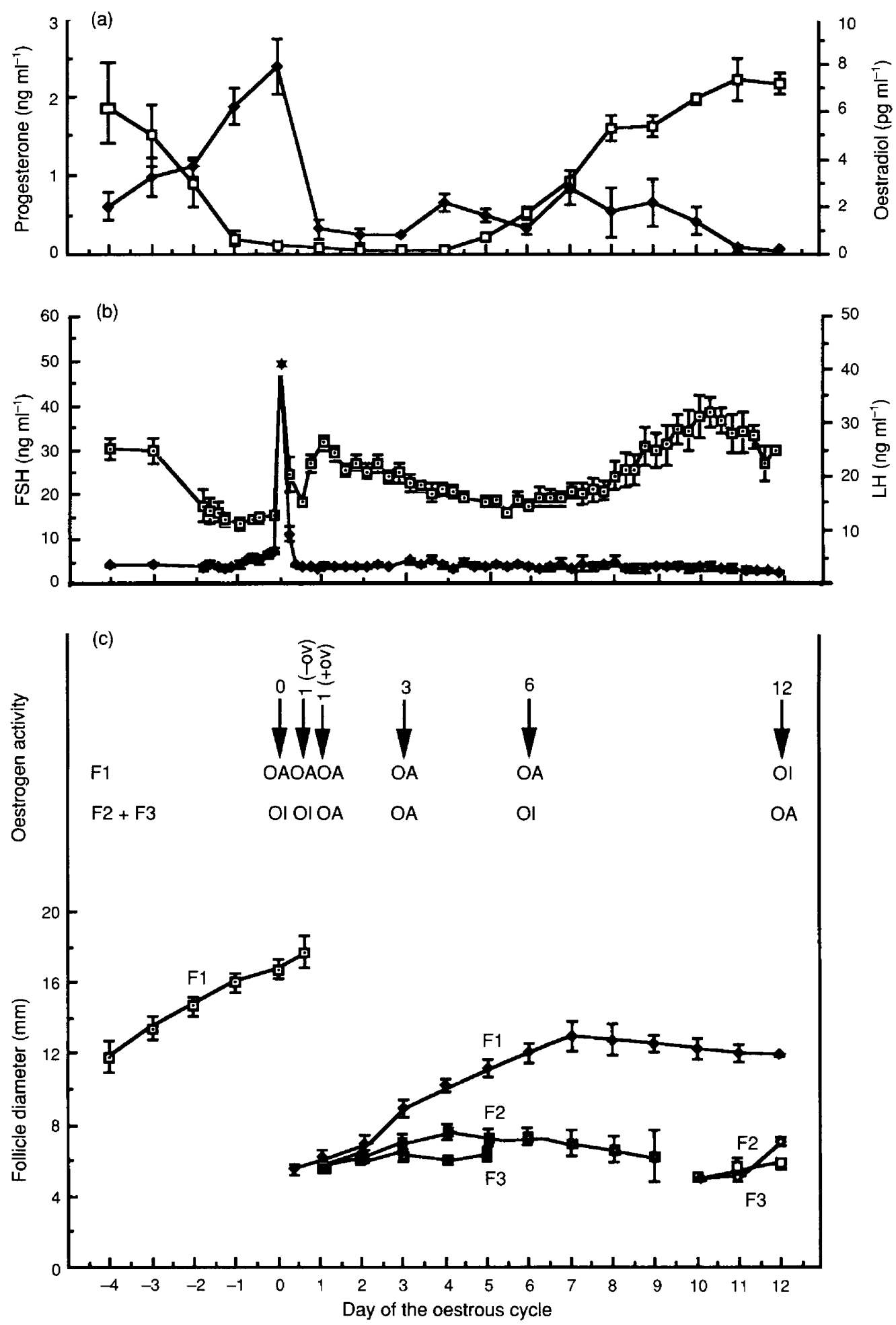
$I(+o v)$ to $13 \pm 0.8 \mathrm{~mm}$ by day 7 . Thereafter, the size of this F1 follicle did not change $(P>0.05)$ up to the time of ovariectomy on day 12 (Fig. 1c). Coincident with development of the dominant nonovulatory follicle were two transient increases $(P<0.02)$ in the serum concentration of FSH between days 0.5 and 1.5 , and days 8 and 10.5 of the oestrous cycle. During the early luteal phase, the serum LH concentration remained unchanged $(P<0.05)$, whereas transient increases $(P<0.05)$ in serum concentration of oestradiol occurred during days 3-10 when FSH concentrations were low. In contrast to the time from day -4 to day -1 of the follicular phase, F2 and F3 follicles were both $\geq 5 \mathrm{~mm}$ during the early dioestrous phase. In addition, the diameter of F2 and F3 follicles increased $(P<0.05)$ during days $\mathrm{I}-4$ and then decreased to $<5 \mathrm{~mm}$ in diameter during days 5-10. A new group of F2 and F3 follicles emerged between days 10 and 12 (Fig. 1c).

Similar to the dominant ovulatory follicle, the dominant nonovulatory follicle on days 1,3 and 6 was classified as oestrogen-active (Figs Ic, 2). It should be noted that the F1, or the largest follicle was not always the dominant nonovulatory follicle until after day 4 (Fig. 3). Unlike F2 and F3 follicles on day 0 and day 1 ( - ov), F2 and F3 follicles on days 1 ( + ov) and 3 of the early luteal phase were oestrogen-active (Figs Ic, 2). The emerging medium follicles of the second wave were also all oestrogen-active on day 12 .

Although concentrations of progesterone in follicular fluid were greater $(P<0.05)$ in the F2 and F3 follicles than in the F1 follicle on day $1(+o v)$, size, oestradiol concentration, and the ratio of oestradiol:progesterone concentrations were similar for all follicle classes (Figs Ic and 2), and oestradiol, progesterone and the ratio of oestradiol:progesterone concentrations were not correlated with the size of follicles (Table 1). On day 3, only diameter (by ultrasound) and the volume of follicular fluid were greater for F1 compared with F2 and F3 follicles, and the size of follicles was correlated $(r=0.59 ; P<0.03)$ with oestradiol concentrations in follicular fluid. On day 6, all indices of follicle size, oestradiol concentration in follicular fluid and the ratio of oestradiol:progesterone concentrations in follicular fluid were greater $(P<0.05)$ for dominant nonovulatory follicles than for F2 follicles, and size of follicles was highly correlated $(r>0.70 ; P<0.02)$ with the ratio of oestradiol: progesterone concentrations in follicular fluid (Table 1). Although all indices for size were greater $(P<0.05)$ for dominant nonovulatory follicles compared with F2 or F3 follicles on day 12, the concentration of oestradiol and the ratio of oestradiol:progesterone concentrations in follicular fluid were greater $(P<0.05)$ in F2 and F3 follicles than in the dominant nonovulatory follicle (F1; Figs 1c, 2). In contrast, the concentration of progesterone was greater in dominant nonovulatory follides (F1) than in F2 follicles on day 12 (Fig. 2). The size of follicles on day 12 was correlated $(r=0.56$; $P<0.02$ ) only with progesterone in follicular fluid (Table 1 ).

The overall correlation between ultrasound and calliper measurements of diameter $(r=0.92 ; P<0.0001)$ and volume $(r=0.88 ; P<0.0001)$ of F1, F2 and F3 follicles after ovariectomy was very high (Table 1 ). However, ultrasound measurements of diameter were not correlated $(P>0.05)$ with diameter and volume of follicles after ovariectomy on day 1 ( + ov) or day 3, or for F3 follicles.

The proportion of the largest follicles with the greatest concentrations of oestradiol, progesterone, oestradiol:progesterone or progesterone:oestradiol ratios was similar regardless of whether follicle size was measured by ultrasound or with callipers after ovariectomy (Table 2 ). The predictability of the proportion of the largest follicles that became dominant increased $(P<0.002)$ from $0 \%$ on day $I$ to $100 \%$ by day 5 of the oestrous cycle (Fig. 3).

\section{Discussion}

This is the first report to evaluate the relationship between ultrasound monitoring of follicular growth and measures of follicular growth and function after ovariectomy. Our results indicate that ultrasound and postovariectomy measurements of follicle size are highly correlated, implying that ultrasound is an accurate method for monitoring follicular growth. However, the greatest correlation of ultrasound and postovariectomy measures of follicular growth occurred when a single dominant follicle was present during the follicular and luteal phases of the oestrous cycle. In contrast, when a clear hierarchy of follicles was not established, as on days 1 and 3 after ovulation, ultrasound measurements were not significantly correlated with postovariectomy measures of follicle size. While the reason for this finding is unclear, results of correlation analysis have indicated that ultrasound and postovariectomy measurements of follicular growth are least correlated when follicles are classified as F3 (usually $5-6 \mathrm{~mm}$ in diameter). Thus, the accuracy of measuring these follicles, regardless of the method used to estimate size, may be diminished compared with measurements of larger antral follicles.

In support of the accuracy of ultrasound measurements for large follicles, both ultrasound and two different

Fig. 1. Mean ( \pm SEM) changes in (a) serum concentrations of progesterone ( $\square$; $\mathrm{ng} \mathrm{ml}^{-1}$ ) and oestradiol ( $\bullet$; pg ml ${ }^{-1}$ ), (b) serum concentrations of FSH ( $($ ) and LH ( $)$ (ng ml ${ }^{-1}$ ), and (c) size of antral follicles during oestrus and early dioestrus of the oestrous cycle of heifers. Daily ultrasound measurements were made on each heifer beginning 4 days before oestrus until ovariectomy. Each point either represents (c) the daily mean ( \pm SE) for diameter of F1, F2 and F3 follicles, or (b) means ( \pm SE) every $6 \mathrm{~h}$ for serum concentrations of LH and FSH or (a) daily mean ( \pm SE) serum concentrations for progesterone and oestradiol for 5-33 heifers. Arrows in (c) indicate that groups of heifers ( $n=5-6$ per treatment) were ovariectomized on day 0 , day 1 after the preovulatory LH surge, but before ovulation [1 ( - ov)], day 1 after ovulation [1 ( + ov)], day 3 , day 6 and day 12 of the oestrous cycle. Follicles were separated into three classes based on ultrasound measurement of diameter (F1, largest follicle; F2, second largest; F3, all the remaining follicles $\geq 5 \mathrm{~mm}$ ), and oestrogen activity [oestradiol:progesterone ratio $>1$; oestrogen-active (OA) or oestradiol:progesterone ratio < 1 ; oestrogen inactive $(\mathrm{OI})$ ]. The oestrogen activity for the F1, F2 and F3 follicles on the six times of ovariectomy is indicated below the arrows for the respective days. On days 0 and $1(-o v), F 1$ is the dominant ovulatory follicle. On days 1 ( + ov) to day 3 , ultrasound measurements of follicle size cannot be used accurately to predict which follicle is dominant. However, on days 4-12, F1 is the dominant nonovulatory follicle. Note that all 33 heifers are included between 4 days before oestrus and ovariectomy (day 0 ); thereafter, numbers of heifers were reduced by $5-6$ after each ovariectomy (indicated by arrows). 
(a)

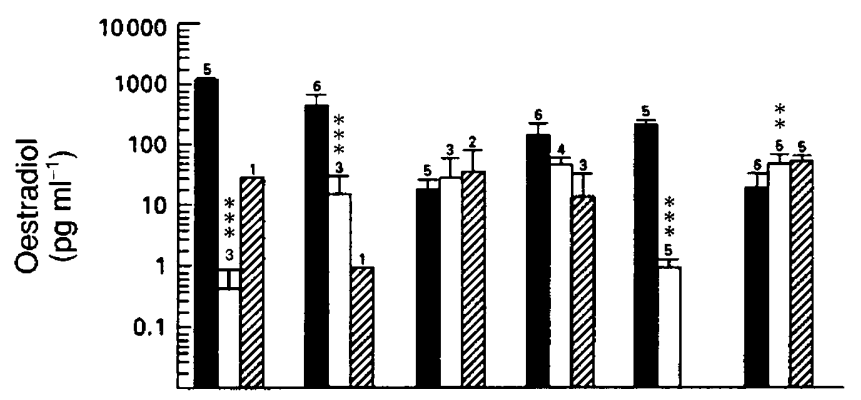

(b)

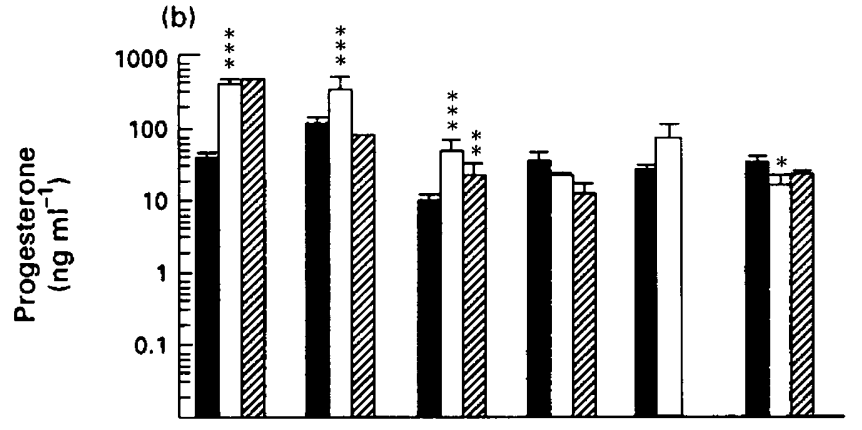

(c)

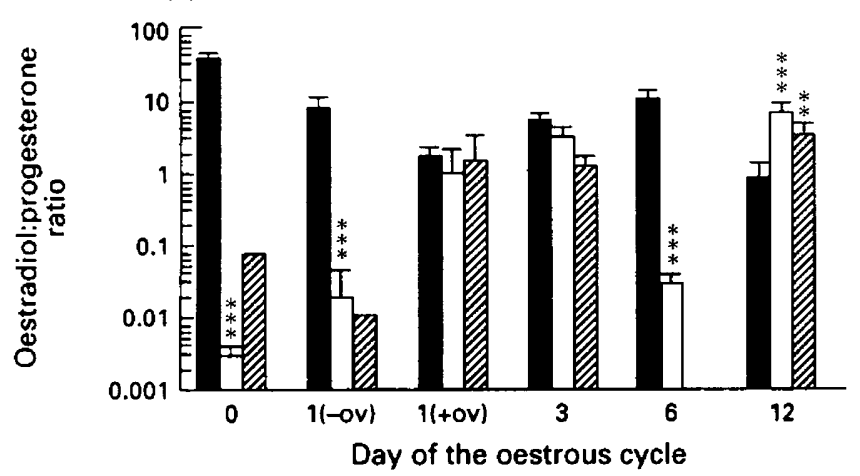

Fig. 2. Changes in the concentrations of (a) oestradiol, (b) progesterone and (c) ratio of oestradiol:progesterone concentrations in follicular fluid for follicles $\geq 5 \mathrm{~mm}$ in diameter during oestrus and early dioestrus of the oestrous cycle of heifers. Ultrasound was used to monitor growth and classify follicles as F1 (largest; $\mathbf{c}$ ), F2 (second largest; $\square$ ) or F3 (remaining follicles $\geq 5 \mathrm{~mm}$; $(\mathbb{1})$ ) in six different groups of heifers ( $n=5-6$ heifers per group). Bars represent means $( \pm \mathrm{SE})$ and asterisks above bars indicate whether means for FI follicles differed statistically $\left({ }^{*} P<0.10,{ }^{*} P<0.05, * * * P<0.01\right)$ from $\mathrm{F} 2$ or F3 follicles within a certain day. The number of follicles measured is shown in the top panel. - ov: preovulation; +ov: postovulation.

postovariectomy measurements of follicle size, diameter and volume were used to determine whether the proportion of the largest follicles (excluding the largest follicle on day 12) with the highest concentration of oestradiol, progesterone, oestradiol:progesterone or progesterone:oestradiol ratios differed. Regardless of which method was used to measure follicle size, the results were similar. Finally, the pattern of turnover of follicles of heifers during days $0-12$ is similar to previous reports (Savio et al., 1988; Sirois and Fortune, 1988; Knopf

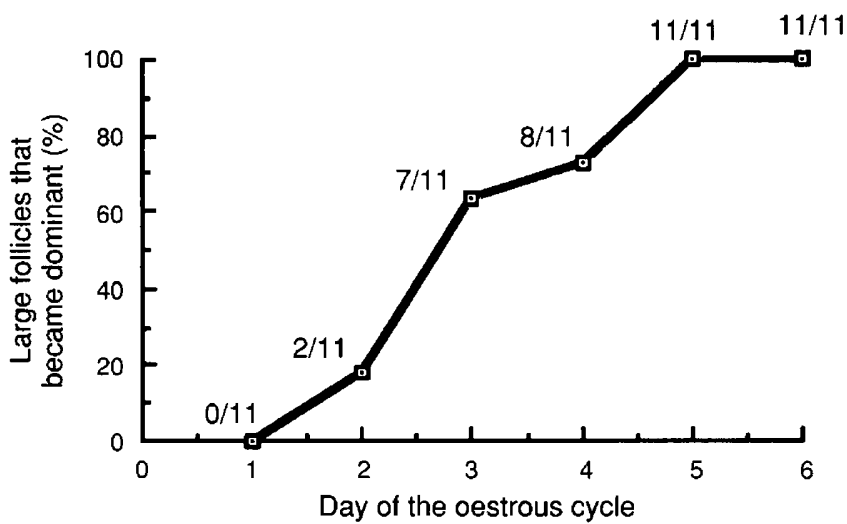

Fig. 3. Proportion of dominant follicles on days 6 and 12 of the oestrous cycle of heifers identified by ultrasound that were also the largest follicles on days 1-6. Follicle growth was monitored daily by ultrasound for 11 heifers from 4 days before oestrus until ovariectomy on days 6 and 12. Data for heifers ovariectomized on days 1 and 3 were excluded because ultrasound measurements could not be accurately used on these days to establish which follicle would become dominant. Numbers represent the number of dominant follicles on days 6 and 12 identified as the largest follicles on days 1-6, divided by the total number of dominant follicles.

et al., 1989; Adams et al., 1992; Badinga et al., 1992). On the basis of results of this study and those of others (Sirois and Fortune, 1988; Knopf et al., 1989; Adams et al., 1992; Badinga et al., 1992), ultrasound analysis is an accurate and consistent procedure for monitoring the size and turnover of follicles $\geq 5 \mathrm{~mm}$ during the oestrous cycle of heifers.

During the oestrous cycle, follicles are recruited into a growing pool and the number selected to continue growing to become dominant follicles is equivalent to the species-specific ovulatory quota (Goodman and Hodgen, 1983). However, the factors involved in selection of dominant follicles are unknown. The completion of a selection phase is defined in cattle by both ultrasound measurements (Savio et al., 1988; Sirois and Fortune, 1988) and the intrafollicular ratio of oestradiol:progesterone concentrations (Ireland and Roche, 1982, 1983a, b) as the time when an oestrogen-active follicle promotes its own growth and inhibits the growth of other follicles. In our study, we examined whether the size of a follicle influenced whether it would become dominant and whether the largest follicles had the highest concentration of oestradiol. The results indicated that the early dioestrus dominant nonovulatory follicle was usually not the largest follicle ( 2 of 22 measurements) on days 1 and 2 of the oestrous cycle, but was usually the largest after day 2 (37 of 44). Although the concentration of oestradiol and the ratio of oestradiol:progesterone concentrations were not different for each follicle $\geq 5 \mathrm{~mm}$ on day 1 after ovulation, concentrations of progesterone were greater in the F2 and F3 than in the FI follicles. These results indicate that factors other than size and oestradiol concentrations, such as progesterone, may be important for establishing which follicle becomes dominant during a selection phase.

Although the largest follicle with the greatest concentration of oestradiol during a selection phase does not always become dominant, functioning dominant follicles during the follicular phase and on day 6 of the oestrous cycle were always the 
Table 1. Correlation of ultrasound measurements of follicle diameter with calliper measurements of diameter, volume of follicular fluid and concentrations of oestradiol, progesterone and the ratio of oestradiolprogesterone concentrations in follicular fluid during the oestrous cycle of heifers ${ }^{a}$

\begin{tabular}{|c|c|c|c|c|c|c|}
\hline Day of cycle & $n$ & Diameter & Volume & Oestradiol & Progesterone & Oestradiol:progesterone \\
\hline 0 & 9 & $\begin{array}{l}0.94^{b} \\
(0.0001)^{c}\end{array}$ & $\begin{array}{l}0.93 \\
(0.0001)\end{array}$ & $\begin{array}{l}0.90 \\
(0.001)\end{array}$ & $\begin{array}{l}0.83 \\
(0.006)\end{array}$ & $\begin{array}{c}0.76 \\
(0.02)\end{array}$ \\
\hline$I(-$ ov $)$ & 10 & $\begin{array}{l}0.96 \\
(0.001)\end{array}$ & $\begin{array}{l}0.88 \\
(0.001)\end{array}$ & $\begin{array}{r}0.40 \\
\text { ns }\end{array}$ & $\begin{array}{r}0.37 \\
\text { ns }\end{array}$ & $\begin{array}{r}0.38 \\
\text { ns }\end{array}$ \\
\hline$I(+o v)$ & 10 & $\begin{array}{r}0.51 \\
\text { ns }\end{array}$ & $\begin{array}{r}0.14 \\
\mathrm{~ns}\end{array}$ & $\begin{array}{r}0.17 \\
\text { ns }\end{array}$ & $\begin{array}{r}0.05 \\
\text { ns }\end{array}$ & $\begin{array}{r}0.27 \\
\text { ns }\end{array}$ \\
\hline 3 & 13 & $\begin{array}{r}0.43 \\
\text { ns }\end{array}$ & $\begin{array}{r}0.45 \\
\mathrm{~ns}\end{array}$ & $\begin{array}{c}0.59 \\
(0.03)\end{array}$ & $\begin{array}{r}0.00 \\
\mathrm{~ns}\end{array}$ & $\begin{array}{r}0.49 \\
\mathrm{~ns}\end{array}$ \\
\hline 6 & 10 & $\begin{array}{l}0.88 \\
(0.001)\end{array}$ & $\begin{array}{l}0.88 \\
(0.001)\end{array}$ & $\begin{array}{c}0.74 \\
(0.01)\end{array}$ & $\begin{array}{r}0.11 \\
\mathrm{~ns}\end{array}$ & $\begin{array}{c}0.70 \\
(0.02)\end{array}$ \\
\hline 12 & 16 & $\begin{array}{l}0.92 \\
(0.0001)\end{array}$ & $\begin{array}{l}0.91 \\
(0.0001)\end{array}$ & $\begin{array}{r}0.25 \\
\text { ns }\end{array}$ & $\begin{array}{c}0.56 \\
(0.02)\end{array}$ & $\begin{array}{r}0.29 \\
\mathrm{~ns}\end{array}$ \\
\hline $\begin{array}{l}\text { Overall }^{\mathrm{d}} \\
\text { F1 }\end{array}$ & 33 & $\begin{array}{l}0.93 \\
(0.0001)\end{array}$ & $\begin{array}{l}0.89 \\
(0.0001)\end{array}$ & $\begin{array}{l}0.47 \\
(0.005)\end{array}$ & $\begin{array}{l}0.57 \\
(0.001)\end{array}$ & $\begin{array}{r}0.32 \\
\text { ns }\end{array}$ \\
\hline $\mathrm{F} 2$ & 23 & $\begin{array}{c}0.46 \\
(0.03)\end{array}$ & $\begin{array}{l}0.68 \\
(0.0001)\end{array}$ & $\begin{array}{r}0.03 \\
n s\end{array}$ & $\begin{array}{r}0.40 \\
\mathrm{~ns}\end{array}$ & $\begin{array}{r}0.07 \\
\text { ns }\end{array}$ \\
\hline F3 & 12 & $\begin{array}{r}0.13 \\
\text { ns }\end{array}$ & $\begin{array}{r}0.09 \\
\text { ns }\end{array}$ & $\begin{array}{r}0.28 \\
\mathrm{~ns}\end{array}$ & $\begin{array}{c}0.68 \\
(0.01)\end{array}$ & $\begin{array}{r}0.68 \\
n s\end{array}$ \\
\hline$F_{1}+F_{2}+F_{3}$ & 68 & $\begin{array}{l}0.92 \\
(0.0001)\end{array}$ & $\begin{array}{l}0.88 \\
(0.0001)\end{array}$ & $\begin{array}{l}0.55 \\
(0.0001)\end{array}$ & $\begin{array}{r}0.09 \\
\text { ns }\end{array}$ & $\begin{array}{l}0.43 \\
(0.0001)\end{array}$ \\
\hline
\end{tabular}

${ }^{a}$ Groups of five or six heifers were ovariectomized on six different days of the oestrous cycle and follicles were classified as follows: FI, largest follicle; F2, second largest; F3, all remaining follicles $\geqslant 5 \mathrm{~mm}$. The last ultrasound measurement of diameter of follicles $\geqslant 5 \mathrm{~mm}$ was made approximately $14 \mathrm{~h}$ before ovariectomy and correlated with measures of diameter, volume of follicular fluid and concentrations of oestradiol, progesterone and the ratio of oestradiol:progesterone concentrations in follicular fluid determined from the same follicles after ovariectomy. Each heifer had 1-3 follicles $\geqslant 5 \mathrm{~mm}$.

${ }^{\mathrm{b}}$ Regression coefficient.

${ }^{c} P$ value.

${ }^{d}$ Data for all days of the oestrous cycle were combined and correlations within each follicle class examined: F1, largest follicle; F2, second largest follicle; and F3, all other follicles $\geqslant 5 \mathrm{~mm}$.

$n$ : number of follicles; $\mathrm{ns:}$ not significant $(P>0.05)$; - ov: preovulation; +ov: postovulation.

Table 2. Proportion of largest follicles of heifers determined by ultrasound or at ovariectomy that had the highest concentrations of oestradiol, progesterone and ratio of oestradiol:progesterone or progesterone: oestradiol concentrations in follicular fluid ${ }^{\mathrm{a}}$

\begin{tabular}{llll}
\hline Parameter & $\begin{array}{c}\text { Ultrasound } \\
\text { diameter }^{b}\end{array}$ & Diameter & At ovariectomy \\
\hline Oestradiol & $22 / 27(81 \%)^{c}$ & $25 / 27(93 \%)^{c}$ & $25 / 27(93 \%)^{c}$ \\
Progesterone & $12 / 27(44 \%)^{d}$ & $14 / 27(52 \%)^{d}$ & $12 / 27(44 \%)^{d}$ \\
Oestradiol:progesterone & $25 / 27(93 \%)^{c}$ & $25 / 27(93 \%)^{c}$ & $25 / 27(93 \%)^{c}$ \\
Progesterone:oestradiol & $11 / 27(41 \%)^{\mathrm{d}}$ & $11 / 27(41 \%)^{\mathrm{d}}$ & $11 / 27(41 \%)^{\mathrm{d}}$ \\
\hline
\end{tabular}

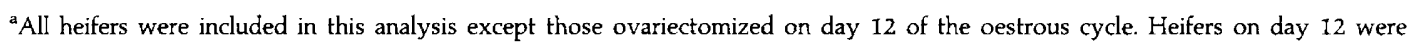
excluded because all the largest follicles were atretic.

${ }^{b}$ The last ultrasound measurement was taken approximately $14 \mathrm{~h}$ before ovariectomy, and was used to determine the largest follicle.

c. dValues with different superscripts are significantly different $(P<0.05)$ between proportions in columns.
}

largest follicles with the highest concentration of oestradiol (Ireland and Roche, 1983a; Martin et al., 1991). However, the F1 follicle on day 12, despite being the largest follicle, had lost its 'functional dominance' as early as day 10, based on the emergence of a new wave of follicular development. The dominant follicle on day 12 was hormonally classified as 
oestrogen-inactive and therefore atretic. Atresia of the dominant nonovulatory follicle is characterized by a significant decrease in the number of granulosa cells, a decrease in both $\mathrm{LH}$ and FSH receptors (Ireland and Roche, 1983b) and a diminished capacity to produce oestradiol between days 7 and 13 of the oestrous cycle in heifers (Badinga et al., 1992). The factors involved in the regulation of atresia of follicles are not clear, but it has been demonstrated that decreasing the $\mathrm{LH}$ pulse frequency to luteal concentrations results in the faster atresia of the dominant follicle (Sirois and Fortune, 1990), suggesting that the dominant ovulatory follicle fails to undergo atresia because it is subjected to a higher $\mathrm{LH}$ pulse frequency in the follicular phase. These results, coupled with those of earlier studies showing that the dominant follicle was not always the largest during a selection phase, clearly indicate that only functioning dominant follicles that are present during finite periods of an oestrous cycle are the largest follicles with the greatest concentration of oestradiol. Although measuring the size or the oestradiol concentration alone is not indicative of whether a follicle will become dominant or whether it is functionally dominant (e.g. preventing growth of other follicles), the ratio of oestradiol:progesterone concentrations can be reliably used to distinguish growing from atretic follicles $\geq 5 \mathrm{~mm}$ in diameter in heifers.

Both ultrasound analysis and the ratio of oestradiol:progesterone concentrations indicate that there are two different periods of growth of multiple follicles $\geq 5 \mathrm{~mm}$ between days 1 and 3 and days 10 and 12 . The results reported here indicate that days 1-3 are the selection phase for development of the early dioestrus dominant nonovulatory follicle, whereas days 10-12 are not only the selection phase for development of the next dominant follicle, but are also the period when the first dominant follicle ceases to function (loses dominance), becomes oestrogen-inactive and begins to undergo atresia. Functional dominance of a follicle begins when a selection phase ends (Goodman and Hodgen, 1983) and is defined as those periods of the oestrous cycle when only a single antral follicle $>5 \mathrm{~mm}$ grows to ovulatory size. In our study, use of ultrasound indicated that there were periods of functional dominance during the follicular phase ( 4 days before oestrus up to the day of ovulation) and from day 4 to day 9 of the oestrous cycle, a finding consistent with previous studies examining follicular dynamics in heifers (Savio et al., 1988; Sirois and Fortune, 1988; Knopf et al., 1989). These periods of functional dominance identified by ultrasound corresponded with the presence of a single large $(\geq 10 \mathrm{~mm})$ oestrogen-active follicle that had greater concentrations of oestradiol and ratio of oestradiol: progesterone concentrations than those for other coexisting follicles (F2, F3). Although our results do not indicate precisely when the selection phase begins or ends and when dominance begins, an easily distinguishable hierarchy of follicles was clear by day 4 of the oestrous cycle. In contrast, despite the presence of multiple potential dominant follicles on days 1 (after ovulation), 3 and 12 (based on the ratio of oestradiol:progesterone concentrations), a functional dominant follicle was not present on these days of the oestrous cycle. This finding is supported by both ultrasound and hormonal analysis indicating that multiple, rather than a single, oestrogen-active follicles were growing during these times and that the first dominant follicle was oestrogen-inactive and undergoing atresia by day
12. Ultrasound analysis also indicates that the F2 and F3 follicles on days 4-10, which were present when the functional dominant ovulatory follicle was present on the ovary, and the dominant (F1) nonovulatory follicle on day 12 were either not growing or had lost functional dominance and were also identified as oestrogen-inactive.

This is the first study to characterize the relationship between changing FSH concentrations and intrafollicular changes in the ratio of oestradiol:progesterone concentrations as follicles develop and regress. Both selection periods of follicular growth, days $1-3$ and days $10-12$, are preceded by a rise in serum concentrations of FSH. Our results, using samples taken every $6 \mathrm{~h}$ and both ultrasound and the ratio of oestradiol: progesterone concentrations as methods of monitoring follicular growth, confirm the findings of Adams ef al. (1992), who used daily blood samples and ultrasound to demonstrate that an increase in FSH occurred 2-4 days before a new wave of follicle development. FSH has a deterministic role in all stages of follicular development (Richards, 1980); thus, it is hypothesized that increases in circulating concentrations of FSH initiate the emergence phase for dominant follicle growth.

This hypothesis is supported by recent data which demonstrate that delaying the first rise in FSH after ovulation between days 0 and 3 by administering bovine follicular fluid delays the emergence of a new dominant follicle (Adams et al, 1992). Removal of the inhibitory influences of the dominant follicle by ovariectomy on days 3,5 and 8 of the oestrous cycle increases both the FSH concentration and the number of small follicles, and advances the emergence of a new dominant follicle (Adams et al., 1992). Thus, our data provide compelling evidence for a cyclic pattern of FSH secretion during the oestrous cycle of cattle, and this FSH secretion is responsible for the emergence and selection of follicle growth. Once selection is complete as indicated by the presence of one oestrogen-active follicle, the circulating concentrations of FSH have decreased, suggesting that the dominant follicle secretes some inhibitory substance(s) to decrease FSH. It is now well established that both oestradiol (Price and Webb, 1988) and inhibin (Beard et al., 1990; Rivier and Vale, 1991; Robertson et al., 1991), produced by the follicle, control the release of FSH in a negative fashion. The relative importance of both hormones in the regulation of $\mathrm{FSH}$ concentration is not clear, but the endocrine data generated in this experiment (Fig. 1) indicate that there is not a clear negative association between serum concentrations of FSH and oestradiol at all stages of the oestrous cycle. These findings suggest that inhibin is important for the regulation of $\mathrm{FSH}$, but owing to the lack of a specific inhibin assay to measure biologically active inhibins (Ireland et al., 1994), it is not yet possible to demonstrate such an effect. Despite this decrease in the circulating FSH concentration after selection and the atresia of all but one follicle, the dominant follicle continues growing, demonstrating that large amounts of FSH are not necessary to sustain follicular dominance.

We conclude that (I) ovarian follicles go through distinct phases of selection, growth, dominance and atresia resulting in the cyclic development of dominant ovulatory and dominant nonovulatory follicles throughout the bovine oestrous cycle, and FSH is probably the physiological 'trigger' for this cyclic follicle growth pattern; (2) the methods of ultrasound and the intrafollicular ratio of oestradiol:progesterone concentrations 
must be combined to monitor dominant follicle growth, function and atresia accurately; and (3) the original model for dominant follicle growth (Ireland and Roche, 1987) was a valid physiological representation of dominant follicle turnover during the oestrous cycle of heifers.

The authors are grateful to M. Looby, M. Mihm, J. Walsh, T. Sweeney, D. O'Callaghan, P. Duffy, F. Griffith, A. Baguisi, C. Burke, W. Enright, D. Prendiville and R. Mantovani for assistance with surgery and collection of samples and data, N. Hynes, S. McDonald and $\mathrm{S}$. Ni Cheallaigh for assistance with radioimmunoassays, D. Williams and L. Chapin for assistance with statistics and data analysis, $T$. Harte and the staff at Lyons Research Farm for the maintenance and care of experimental animals, NIDDK (Baltimore, MD) for providing oLH (AFP-192279) and oFSH (AFP-C5288113) antisera and LH hormone preparations (bLH I1, AFP-6000 and NIH-LH-B9), D. Bolt (USDA) for providing FSH hormone preparations and Clonatec Ltd, Paris for providing progesterone antiserum $(\mathrm{Pi} 531$, lot 5). This research was supported by UCD. The National Agricultural and Veterinary Biotechnology Programme of BioResearch, Ireland, USDA grants 88-37240-4104 and 90-37240-5508, and Research Excellence Funds from Michigan State University to J. J. Ireland. J. J. Ireland is a member of the National Center for Infertility Research at the University of Michigan.

\section{References}

Adams GP, Matteri RL, Kastelic JP, Ko JCH and Ginther OJ (1992) Association between surges of follicle-stimulating hormone and the emergence of follicular waves in heifers Journal of Reproduction and Fertility 94 177-188

Badinga L, Driancourt MA, Savio JD, Wolfenson D, Drost M, De Le Sota RL and Thatcher WW (1992) Endocrine and ovarian responses associated with the first-wave dominant follicle in cattle Biology of Reproduction 47 871-883

Beard AJ, Castillo RJ, McLeod BJ, Glencross RG and Knight PG (1990) Comparison of the effects of crude and highly purified bovine inhibin $\left(M_{\mathrm{r}} 32,000\right)$ on plasma concentrations of FSH and $\mathrm{LH}$ in chronically ovariectomized prepubertal heifers Journal of Endocrinology 125 21-30

Choudary JB, Gier HT and Marion GB (1968) Cyclic changes in bovine vesicular follicles Journal of Animal Science 27 468-471

Crowe MA, Goulding D, Baguisi A, Boland MP and Roche JF (1993) Induced ovulation of the first postpartum dominant follicle in beef suckler cows using a GnRH analogue Journal of Reproduction and Fertility 99 551-555

Drost M, Savio JD, Barros CM, Badinga L and Thatcher WW (1992) Ovariectomy by colpotomy in cows Joumal of American Veterinary Medicine Association $200337-339$

Dufour J, Whitmore HL, Ginther OJ and Casida LE (1972) Identification of the ovulating follicle by its size on different days of the estrous cycle in heifers Journal of Animal Science 34 85-87

Gill JL (1978) Design and Analysis of Experiments in the Animal and Medical Sciences (Vol. 1), Iowa State University Press 828425

Glencross RG, Bleach ECL, McLeod BJ, Beard AJ and Knight PG (1992) Effect of active immunization of heifers against inhibin on plasma FSH concentrations, ovarian follicular development and ovulation rate Journal of Endocrinology $13411-18$

Goodman AL and Hodgen GD (1983) The ovarian triad of the primate menstrual cycle Recent Progress in Hormone Research $391-73$

Ireland JJ (1987) Control of follicular growth and development Journal of Reproduction and Fertility Supplement 34 39-54

Ireland JJ and Roche JF (1982) Development of antral follicles in cattle after prostaglandin-induced luteolysis: changes in serum hormones, steroids in follicular fluid, and gonadotropin receptors Endocrinology 111 2077-2086

Ireland JJ and Roche JF (1983a) Development of nonovulatory antral follicles in heifers: changes in steroids in follicular fluid and receptors for gonadotropins Endocrinology 112 150-156
Ireland JJ and Roche JF (1983b) Growth and differentiation of large antral follicles after spontaneous luteolysis in heifers: changes in concentration of hormones in follicular fluid and specific binding of gonadotropins to follicles Journal of Animal Science 57 157-167

Ireland JI and Roche JF (1987) Hypotheses regarding development of dominant follicles during a bovine estrous cycle. In Follicular Growth and Ovulation Rate in Farm Animals pp I-18 Eds JF Roche and D O'Callaghan. Martinus Nijhoff Publishers, Dordrecht

Ireland JJ, Fogwell RL, Oxender WD, Ames K and Cowley JL (1985) Production of estradiol by each ovary during the estrous cycle of cows Joumal of Animal Science 59 764-771

Ireland JLH, Good TEM, Knight PG and Ireland JJ (in press) Alterations in amounts of different forms of inhibin during follicular atresia Biology of Reproduction

Knopf L, Kastelic JP, Schallenberger E and Ginther OJ (1989) Ovarian follicular dynamics in heifers: test of two-wave hypothesis by ultrasonically monitoring individual follicles Domestic Animal Endocrinology 6 111-119

Marion GB, Gier HT and Choudary JB (1968) Micromorphology of the bovine ovarian follicular system Journal of Animal Science 27 451-465

Martin TL, Fogwell RL and Ireland JJ (1991) Concentrations of inhibins and steroids in follicular fluid during development of dominant follicles in heifers Biology of Reproduction 44 693-700

Matton P, Adelakoun V, Couture Y and Dufour JJ (1981) Growth and replacement of the bovine ovarian follicles during the estrous cycle Joumal of Animal Science 52 813-820

Moran C, Quirke JF, Prendiville DJ, Bourke S and Roche JF (1991) The effect of estradiol, trenbolone acetate, or zeranol on growth rate, mammary development, carcass traits, and plasma oestradiol concentrations of beef heifers Journal of Animal Science 69 4249-4258

Murphy MG, Boland MP and Roche JF (1990) Pattern of follicular growth and resumption of ovarian activity in post-partum beef suckler cows Journal of Reproduction and Fertility 90 523-533

Niswender GD, Reichert LE, Jr, Midgley AR, Jr and Nalbandov AV (1969) Radioimmunoassay for bovine and ovine luteinizing hormone Endocrinology 84 1166-1173

Price CA and Webb R (1988) Steroid control of gonadotropin secretion and ovarian function in heifers Endocrinology 122 2222-2231

Rajakoski E (1960) The ovarian follicular system in sexually mature heifers with special reference to seasonal, cyclical, and left-right variations Acta Endocrinologica 52 7-68

Richards JS (1980) Maturation of ovarian follicles: actions and interactions of pituitary and ovarian hormones on follicular cell differentiation Physiology Reviews 60 51-89

Rivier C and Vale W (1991) Effect of recombinant inhibin on follicle stimulating hormone secretion by the female rat: interaction with a gonadotrophinreleasing hormone antagonist and estrogen Endocrinology 129 2160-2165

Robertson DM, Prisk M, McMaster JW, Irby DC, Findlay JK and deKretser DM (1991) Serum FSH-suppressing activity of human recombinant inhibin A in male and female rats Journal of Reproduction and Fertility 91 321-328

Ronayne E and Hynes N (1990) Measurement of plasma progesterone concentrations by extraction and non-extraction radioimmunoassays Irish Journal of Agricuitural Research 29 109-115

SAS (1986) SAS User's Guide. Statistical Analysis System, Cary NC

Savio JD, Keenan L, Boland MP and Roche JF (1988) Pattern of growth of dominant follicles during the oestrous cycle of heifers Journal of Reproduction and Fertility $83663-671$

Savio JD, Boland MP, Hynes N and Roche JF (1990) Resumption of follicular activity in the early post-partum period of dairy cows Journal of Reproduction and Fertility 88 569-579

Sirois J and Fortune JE (1988) Ovarian follicular dynamics during the estrous cycle in heifers monitored by real-time ultrasonography Biology of Reproduction 39 308-317

Sirois J and Fortune JE (1990) Lengthening the bovine estrous cycle with low levels of exogenous progesterone: a model for studying ovarian follicular dominance Biology of Reproduction 127 916-925

SYSTAT (1990) SYSTAT: The System for Statistics. Systat Inc., Evanston, IL 